\title{
Effect of cropland and livestock ownership on child labour in eastern Ethiopia: empirical examination of the Wealth Paradox
}

\author{
Arega Shumetie ${ }^{1 *}$ and Kassahun Mamo ${ }^{2}$
}

\author{
*Correspondence: \\ ashueconomist@gmail.com \\ ${ }^{1}$ Department of Economics, \\ Debre Markos University, \\ Debre Markos, Po.Box. 126, \\ Ethiopia \\ Full list of author information \\ is available at the end of the \\ article
}

\begin{abstract}
The study examined the relationship between child labour participation and household wealth (in terms of livestock and cropland) considering representative sample smallholders from four (Kurfa Chelie, Kersa, Fedis, and Melka Bello) districts in eastern Hararghe Zone of Oromia regional state of Ethiopia. The descriptive statics showed that average family size was 5.45 individuals per household, which was larger than the national average (4.9) in 2016. In the study area, children with age interval of 4-14 years, that were the subject matter of this study, constituted $43.3 \%$ of the total population. Around 23\% of sampled households spent less than 2471.22 Birr per annum per adult equivalent for home consumption, which is an amount based on the inflation adjusted poverty line. Households in Fedis district experienced the worst poverty head count score, wherein $44 \%$ of them could not satisfy the minimum living standard requirement. Double-hurdle model result revealed that livestock and cropland holding of smallholders significantly affect child labour participation in domestic work. This finding implies that household's asset ownership (possession of larger livestock and cropland) would not initiate children to budget more time for their education. The model result also showed that household head's education level significantly reduced children's domestic labour participation in the study area. Thus, this research recommended that there should be improvement in households' education and awareness level in the study area to improve child school enrolment. Finally, it is easy to say that the Wealth Paradox about child labour holds true for smallholders in eastern Ethiopia.
\end{abstract}

Keywords: Child labour, Cropland, Livestock, Wealth paradox, Household, Child Education

\section{Introduction}

Child labour exploitation is one of the development challenges that most developing countries experienced commonly. Worldwide, 218 million children of ages 5-17 are involved in child labour (ILO 2017), wherein 126 million work in dangerous conditions. In sub-Saharan Africa alone $29 \%$ of the labour force sourced from children with ages of 5-14 (ILO 2000). Persistent poverty and labour intensive nature of the economic activity, which is an agrarian type, are the pillar reasons for the child labour exploitation and low schooling (FAO 2006). This is also true in Ethiopia, wherein $85 \%$ of the population is

(c) The Author(s) 2019. This article is distributed under the terms of the Creative Commons Attribution 4.0 International License (http://creativecommons.org/licenses/by/4.0/), which permits unrestricted use, distribution, and reproduction in any medium, provided you give appropriate credit to the original author(s) and the source, provide a link to the Creative Commons license, and indicate if changes were made. 
dwelling in rural areas and purely dependent on traditional agriculture. Significant proportion of the population in the country is youth even though there is lack of employment opportunities (Guarcello et al. 2006).

In Ethiopia, children below 18 years comprise half of the total population and majority of them engaged in any form of economic activities (Guarcello and Rosati 2007). Hence, the country can be considered among nations having the highest rates of child labour in the world. One-half of all the 5-14-year-old children (more than 7.5 million) were at work in the different economic sectors of the country, wherein agriculture takes the significant proportion (Lorenzo and Furio 2007). Four out of five economically active children are in agriculture, while only 12 and $4 \%$ are in services and manufacturing, respectively. About $80 \%$ of the rural children (5-14 years) participated in any sort of economic activities, but only $15 \%$ of the urban children do the same. The participation rate of male children exceeds that of female by $20 \%$, although this difference does not consider domestic chores such as water and fuel wood collection, activities solely performed by female children (Guarcello et al. 2006). Although there is substantial variation with contributions ranging up to $50 \%$, about $4-7 \%$ of household income in Ethiopia on average contributed by children (John 2002). This finding suggests that child labour participation in domestic activities has significant income contribution, which is a striking result against the perception of 'children's labour has very low importance'. Based on those findings, children with age interval of $6-15$ years budgeted $58.9 \%$ of the working hours for domestic work and only $18.1 \%$ for school.

Moreover, figures reported by most international agencies overlooked domestic chores and work on family farm, which take prominent share of child labour in most African countries including Ethiopia. The past studies had not consistent result, wherein some argued that poverty is the main cause of child labour, while others evidenced that greater wealth is the reason behind. Majority of the studies supported the positive relationship between household poverty and child labour implying lower child labour participation for wealthier families. On the other hand, Bhalotra and Heady (2003) using data from Pakistan and Ghana, found that larger poverty does not lead to greater child labour. They proposed an interesting analysis on the mere effects of farm size on child labour, Wealth Paradox. The hypothesis argued that children from land-rich households frequently found in domestic work than those from land poor ones. Resource rich households may expect lower return from child schooling and prefer to send their children to work. It follows that, if the household own larger cropland and livestock, it would expect lower return from child schooling. It could be inferior good to cropland and livestock rich households and they might choose child labour as the best venture with regard to benefit. This argument tells us that it is difficult to conclude a priori, whether household wealth has a positive or negative effect on child labour in a particular setting.

Economic activity participation of children rises sharply with age, while $40 \%$ of the youngest (5-9 years) involved at their early age (Guarcello et al. 2006). Children's productivity often constitutes a vital component of household survival and their marginal productivity is about $0.5-0.67$ that of an adult (John 2002). Household demand for labour has been identified as the most important reason for children school dropout in Ethiopia (Takashi 2000). The recent child labour survey revealed that $85 \%$ of them were found to be engaged in some kind of domestic activities and only $38 \%$ were attending 
school (CSA 2009). It was also found that more than $40 \%$ of the children never attend school, while $33 \%$ combined work and schooling. The labour intensive agricultural economy of the country may be the core reason for the significant child labour participations in Ethiopia (Cockburn and Dostie 2007; Edmonds and Pavcnik 2005).

Given this, a better understanding of the nature and trade-off between child labour and schooling in rural Ethiopia is essential to formulate policies aimed at curbing the high incidence of child school dropout. Thus, this study examined the role of household wealth (cropland and livestock) on child labour participation in domestic work in eastern Hararghe. Similarly, the study investigated to what extent does household wealth associated with child school enrolment.

\section{Methodology}

\section{Data source and method of collection}

In most statistics, "child labour" is defined as work for wage, but the definition in this study includes domestic work that consists of chores done inside the house as well as works done outside including livestock management, collection of firewood, fodder, and others. In this study, a child refers all individuals with age interval of 4-14 years. This age group was based on ILO convention for child labour, which is also ratified by Ethiopian government, states that the minimum age of employment should be 15 years and an individual below this should be a child.

This study used primary data collected from farm households in East Hararghe Zone of Ethiopia. The survey covered a total of 400 households in which only one rejected in the analysis due to incomplete data. The sample households selected randomly from each sample village, and this results in having representative sample size.

Well-structured questionnaires and interviews were used to collect data from sampled households. During the survey, data on child characteristics (age, sex and biologically relationship with the household head); household characteristics including (assets and wealth, family size and composition, nature and status of employment, educational level, monthly expenditure, access to credit) were collected. In addition, community level data about access to electricity and piped water, and distance from primary school and market were also collected. The amount of time children spent on work for pay, family farm, and domestic activities such as fetching water and firewood, cooking, and caring also collected.

In addition, focus group discussions in each village were arranged to collect qualitative data for methodological triangulation. The focus group discussion constituted different stakeholders as a community member, local government officials, and NGO representatives. Moreover, key informant interview and discussions were used to substantiate the data collected by all the above methods.

\section{Method of data analysis}

The study employed both descriptive and econometric method of data analysis to achieve the predefined objective, effect of household wealth on child labour participation. There was no method of measuring household wealth; rather, a proxy variable was used in the econometrics analysis. Charles et al. (2014) demonstrate that the productivity of farm land and quality of house are useful proxies for wealth. Land is the most important store 
of wealth in agrarian societies (Sonia and Christopher 2003). In developing country context, cropland and number of livestock owned by the household are the common proxies of wealth (Basu et al. 2010; Koissy-Kpein 2012). Thus, this study considered cropland and livestock size as a proxy in the data analysis process.

In calculating the effect of cropland ownership on child labour, the study used total cropland cultivated, but not the total land owned by the household. Part of the land owned by the household may be rented out and this may not affect the amount of time children spent on farm activities. The livestock size considered after it has been converted into Tropical Livestock Units (TLU). Since the household may own different livestock unit such as cattle, shoat, equines, camel, and others, all of them were converted into TLU using the standardized conversion index for each type.

The previous studies on child labour used a dichotomous dependent variable whether the child participate in certain economic activities or not. Moreover, those studies define child labour as child work for wage only, but this study considered hours of child labour on domestic and farm works. Since these activities consume much of children's time in rural Ethiopia the study considered them in the analysis. The equation modelled child labour as a function of child, household and community characteristics, wealth, and demographic factors of the household (Dawit 2010; Basu et al. 2010).

\section{The double-hurdle model}

Solomon et al. (2010) adopted double-hurdle model, which is simple generalization of the Tobit model (Cragg 1971), unlike the typical binary-dependent variable models for studying the dichotomous issue of the probability and intensity of adopting a new technology. The model has been widely used in the analysis of labour supply behaviour and commodity demand (Smith 2003). The model assumes that two hurdles should be passed to report positive hours of work. The first hurdle relates to the child participation in domestic work, and the second is the level/intensity of work participation. Zero values may be reported in both decisions. The possibility of zero outcomes in the second hurdle arises from the individuals' deliberate choices or random circumstances.

The model can be written as a participation equation:

$$
\begin{aligned}
& d_{i}^{*}=Z_{i} \propto+\varepsilon_{i} \\
& d_{i}=\left\{\begin{array}{ll}
1 & \text { if } \mathrm{d}_{\mathrm{i}}^{*}>0 \\
0 & \text { otherwise }
\end{array},\right.
\end{aligned}
$$

where $d_{i}^{* *}$ is a latent variable that takes a value of 1 if the parents' reported a positive value on children's hours of work and zero otherwise; $Z_{i}$ refers vector of regressors; and $\alpha$ is a vector of parameters to be estimated. If the first "hurdle" is crossed, the second hurdle describes the length of hours the child work. Thus, intensity of work for positive outcomes

$$
\begin{aligned}
& H_{i}^{*}=X_{i} \beta+\mu_{i} \\
& H_{i}=\left\{\begin{array}{l}
H_{i}^{*} \text { if } H_{i}^{*}>0, d_{i}^{*}>0, \\
0 \text { otherwise }
\end{array}\right.
\end{aligned}
$$


where $H_{i}$ is children hours of work, $X_{i}$ is a vector of regressors, and $\beta$ is a vector of parameters that could be estimated. The error terms are assumed to follow a bi-variate normal distribution:

$$
\left(\begin{array}{c}
\epsilon_{i} \\
\mu_{i}
\end{array}\right) \sim N\left[\left(\begin{array}{l}
0 \\
0
\end{array}\right)\left(\begin{array}{cc}
1 & 0 \\
0 & \delta^{2}
\end{array}\right)\right]
$$

The log-likelihood function for the double hurdle is given by

$$
\log L=\sum_{0} \ln \left[1-\Phi\left(z_{i} \alpha\right) \Phi\left(\frac{x_{i} \beta}{\sigma_{u}}\right)\right]+\sum_{0} \ln \left[\Phi\left(z_{i} \alpha\right) \frac{1}{\sigma_{u}} \Phi\left(\frac{y_{i}-x_{i} \beta}{\sigma_{u}}\right)\right] .
$$

The first term in Eq. (6) corresponds to contribution of all the observations with observed zero. In this case, the zero observations are coming not only from participation decision but also from hours of work. The probability in the second term is the product of the conditional probability distribution and density function coming from the censoring rule and observing non-zero values, respectively (Cameron and Trivedi 2005). In this model, the former denotes probability of participation in domestic work, and the latter indicates intensity of work, positive hours.

The log-likelihood of the double-hurdle model originally proposed by Cragg (1971) was separable. It was equivalent to a combination of truncated regression and probit model, provided the assumption of independence between the error terms $\varepsilon_{i}$ and $u_{i}$, stated in Eq. 5 above. Thus, without loss of information, it is possible to maximize the log-likelihood function of the double-hurdle model in a two-step procedure through estimating a probit model on the binary outcome of domestic work participation and thereafter applying a truncated-normal regression on the intensity of participation (McDowell 2018). The model can also allow correlation between the error terms $\left(\varepsilon_{i}\right.$ and $u_{i}$ ) (Fennema and Sinning 2007). This time the two decisions [participation and intensity (hours of work)] are estimated simultaneously to account feedback effect from participation to intensity of work and vice versa. It is assumed that $\varepsilon_{i}$ and $u_{i}$ are distributed as a bi-variants normal distribution:

$$
\left(\begin{array}{c}
\epsilon_{i} \\
\mu_{i}
\end{array}\right) \sim \operatorname{BVN}\left[\left(\begin{array}{l}
0 \\
0
\end{array}\right)\left(\begin{array}{cc}
1 & \rho^{\sigma} \\
\rho^{\sigma} & \delta^{2}
\end{array}\right)\right] .
$$

Thus, the log likelihood of the dependent double-hurdle model becomes

$$
\log L=\sum_{0} \ln \left[1-\Phi\left(Z_{i} \alpha, x_{i} \beta / \sigma, \rho\right)\right]+\sum_{1} \ln \left[\Phi\left(\frac{Z_{i} \alpha+\frac{\rho}{\sigma}\left(y_{i}-x_{i} \beta\right)}{\sqrt{1-\rho^{2}}}\right) \frac{1}{\sigma} \Phi\left(\frac{y_{i}-x_{i} \beta}{\sigma}\right)\right] .
$$

However, this correlation is often difficult to estimate with precision (Smith 2003). Smith argues that the dependent double-hurdle model contains too little statistical information to support estimation of dependency, even if dependency is truly present. Thus, the assumption of independent errors is commonly utilized in the doublehurdle model. If the error terms $\varepsilon_{i}$ and $u_{i}$ are independent $(\rho=0)$, the independent double-hurdle model of Cragg (1971) could be obtained. The Tobit model can be 
regarded as a nested version of the independent double-hurdle model with $\left(z_{i}^{\prime} \alpha\right)=1$ in Eq. (1). In the process, the dependent variable is the child participation in domestic work, which is constructed from the sum total of average hours spending of child labour in chores that includes farming, water fetching, firewood collecting, caring of their younger sibling, and shepherd. Denoting all explanatory variables as $X_{i}$, the following equation specifies the model used in the regression:

$$
\text { Child labor }=\beta^{\prime} X_{i}+\varepsilon_{i} \text {. }
$$

\section{Results and discussion}

\section{Descriptive result}

This part of the study describes the detail about households' characteristics included in the survey, their social indicators and variables that examine economic wellbeing. The descriptive analysis was mainly based on focus group discussion and key informant interview data, which reveal communal problems.

\section{Socio-economic characteristics of households}

The respondents included in the survey had household head with age interval of $18-80$ years, in which $85.7 \%$ of them were 30 or more. Regarding to the gender base classification $23.56 \%$ of the households was female headed. Average family size of the study area was 5.45 , which was greater than the national average rural family size (4.9 per household) (CSA 2008). From the four sampled districts (Kurfa Chelie, Kersa, Fedis and Melka Bello) the first one had the largest family size of 6.17 per household and followed by Melka Bello 5.29 average family size. This statistics is in line with Ethiopian Demography and Health report (2008), which ranks East Hararghe as one of the densely populated areas in the country.

As far as educational status is concerned in the study area is household heads are elementary school graduate (Table 1). Moreover, about $97 \%$ of the sampled household heads had elementary school or below educational achievement.

Children (with the age interval of 4-14 years) constitute $43.3 \%$ of the total family size for households in the study area. Table 2 clearly shows that sample households of the study area had relatively younger heads with average age of 40 years approximately. In addition, households of the study area had lower education level, relatively large dependency ratio, which may create difficulty in reducing poverty and child school dropout problem of the study area.

Table 1 Education background of the sampled households. Source: Own Survey, 2015

\begin{tabular}{llllll}
\hline Indicator variables & Kurfa Chelie & Kersa & Fedis & Melka Bello & All \\
\hline Illiterate & 20.8 & 17.6 & 0.00 & 13.3 & 13.28 \\
Elementary & 71.3 & 81.4 & 100 & 84.8 & 83.96 \\
Secondary & 6.90 & 0.01 & 0.00 & 0.02 & 2.50 \\
Above secondary & 0.01 & 0.00 & 0.00 & 0.00 & 0.003 \\
Total & 100 & 100 & 100 & 100 & 100 \\
\hline
\end{tabular}

The values in the table are percentage 
Table 2 Descriptive statistics of potential covariates. Source: Own Survey, 2015

\begin{tabular}{lllll}
\hline Variable description & Mean & Std. dev. & Min & Max \\
\hline Child labour (in hours) & 4.38 & 4.4 & 0 & 16 \\
Age of household head & 39.78 & 10.76 & 18 & 80 \\
Household head education & 2.29 & 2.22 & 0 & 13 \\
Cropland owned (in hectare) & 0.76 & 0.63 & 0.025 & 4 \\
Hours spent on education per day by & 2.68 & 2.59 & & 10 \\
$\quad$ child & 2.60 & 2.61 & 0 & 35.5 \\
Livestock (in TLU) & 2.31 & 1.44 & 0 & 6 \\
Adult family member & 3.15 & 1.67 & & 10 \\
Dependent family members & & & 0
\end{tabular}

Table 3 Households' poverty gap and severity

\begin{tabular}{lclll}
\hline District & Sample size & $\begin{array}{l}\text { Head count ratio } \\
\left(\boldsymbol{P}_{\mathbf{0}}\right)\end{array}$ & $\begin{array}{l}\text { Poverty gap index } \\
\left(\boldsymbol{P}_{\mathbf{1}}\right)\end{array}$ & $\begin{array}{l}\text { Severity } \\
\text { of poverty } \\
\text { index }\left(\boldsymbol{(}_{\mathbf{2}}\right)\end{array}$ \\
\hline Kurfa Chelie & 101 & 0.079 & 0.039 & 0.027 \\
Kersa & 102 & 0.240 & 0.063 & 0.033 \\
Fedis & 91 & 0.439 & 0.098 & 0.032 \\
Melka Bello & 105 & 0.209 & 0.123 & 0.096 \\
Overall & 399 & 0.230 & 0.081 & 0.048 \\
\hline
\end{tabular}

\section{Households' poverty profile}

This study used the poverty line estimated by Bogale and Korf (2009) for the poverty analysis in the study area. The author estimated that household expenditure on basic needs including food, clothing, education, and medical care is 1468.00 Birr (approximately 120\$) per annum per adult equivalent. This threshold level of household expenditure determined by considering smallholders in the eastern Hararghe highlands. This threshold level of expenditure utilized in this study because of the fact that it is a better poverty line estimate as compared to the national level, since it takes into account the area's special features. After considering this, all the required inflation adjustment has been made using World Bank (2005) inflation for years 2012, 2013, 2014, 2015, and 2016, which were 22.77, 8.08, 7.39, 10.13 and 7.27\% per annum, respectively. Accordingly, this study considered 2471.22 Birr per annum per adult equivalent as a poverty line of expenditure.

Table 3 clearly shows that the overall sample household head count ratio of the study area was 0.23 , which explains that around $23 \%$ of households spent less than what they needed to fulfill their minimum living standard requirement. By decomposing the result into districts Fedis experienced, the worst poverty head count score that is $43.9 \%$ of the households could not satisfy their minimum living standard requirement, followed by Kersa (24\%) and Melka Bello (20.9\%). Besides to the numerical expression of poverty in the study area, personal observation and key informant interviews notified that households in Fedis district are highly dependent on aid. In this regard, both local and foreign NGOs participate indifferent directions to improve the food security and livelihood of smallholders in the area with frequent intervention in Fedis and Kersa districts. The former district frequently suffers from moisture 
stress, which encumbers smallholders to produce few crops (commonly sorghum, maize, groundnut, and k'hat) for their subsistence. Moreover, the study estimated the poverty gap index and severity, and those results also reinforce severity of the problem in the study area (Table 3 ). Based on the overall poverty gap index, on average, $8.1 \%$ (200.17 Birr) of the poverty line is required to take out the poor households above the threshold level (poverty line). However, poor households from Melka Bello district require more than the average amount to free from the deadlock of poverty. There would be in need of $12.3 \%$ of the poverty line (303.96 Birr) on average to break the poverty trap in this district. For the other districts, Fedis, Kersa, and Kurfa Chelie, respectively, about 9.8\% (242.18 Birr), 6.3\% (155.69 Birr) and 3.9\% (96.38 Birr) of the minimum expenditure (poverty line) would be required to take the poor out of poverty (Table 3). Though it lacks intuitive appeal, World Bank (2005) had similar results about the overall severity of poverty index in eastern Ethiopia.

\section{Households' wealth status}

Households of the study area possessed different wealth status and living standard based on the following proxies (Table 4). The livestock holding, measured in terms of Tropical Livestock Unit (TLU), was considered as one proxy variable for household wealth in the study area, and the wealth varied from 0 to $35.5 \mathrm{TLU}$, which revealed large difference among households. Majority of the households (99\%) in the study area possessed livestock of below 10 TLU. The other proxy variable considered for measuring wealth for households in the study area was estimated value of their home, wherein the value ranges from 2000 to 200,000 Birr and the average value was about 20,307 Birr (Table 4).

The study also considered another most important asset as a proxy for wealth that is groundwater, well of borehole. If the household possessed, this important asset it can produce the most important cash crop of the area, K'hat, throughout the year. Households in the study area commonly agreed that this stimulant crop is crucial and main source of cash if there is consistent water supply. This asset creates a visible wellbeing difference between those who have it and not. The survey and key informant interview data indicated that about $6 \%$ of the sample households possessed this important asset, which demands huge budget up to 50,000 Birr (Table 4). Since population of the area is dense, households had very small plot of land on average 0.76 hectares per household. They tried to compensate the huge food crop and cash demand gap by producing better yielding cash crops, particularly $K^{\prime} h a t$, and occasionally, they practiced intercropping that enable them to produce multiple crops.

Table 4 Summary of wealth proxy variables. Source: Own Survey, 2015

\begin{tabular}{llll}
\hline Variable & Minimum & Maximum & Mean \\
\hline Livestock (in TLU) & 0 & 35.5 & 2.60 \\
Land holding (in hectare) & 0.25 & 4 & 0.76 \\
Value of resident home & 2000 Birr & 200,000 Birr & $20,307.52$ Birr \\
Value of groundwater well & 230 Birr & 50,000 Birr & 9124.41 Birr \\
\hline
\end{tabular}

Birr is national currency unit 


\section{Children as a source of family labour}

About $86 \%$ of the surveyed households had at least one child with age of 4-14 years. Those children engaged in various economic activities such as farming, firewood and water fetching, shepherding, and taking care of siblings. Only $3.7 \%$ of the children engaged fully on their education. This clearly shows that households in the study area like many of the developing world use their children as a source of labour to supplement the adult family labour for activities that require less physical exertion. Only $18 \%$ of children attend school and education is not compulsory for children in Ethiopia (Cockburn and Dostie 2007). It is not surprising that school going children come from the highest income households. However, these households' wealth appears to be based especially on the ownership of oxen, bulls, cows, and ploughs, which are basically labour-saving assets not directly involving children. Working children come from significantly lower income households, yet these households have the highest ownership of land and small livestock, two complementary assets that could expect to increase the demand for and return to child work as herders.

Degnet et al. (2007) identified that nationally, about $45 \%$ of the children who enrol in grade one drop out school before completing grade five due to different reasons within the family. The authors identified that poverty demand side factors such as parental education, land, and non-land asset ownership, village fixed effects and a child's demographic characteristics are prominent factors for child schooling progress in Ethiopia. In the focus group discussion, few individuals (especially cash rich ones) argued that the benefit after education is incomparable to the current and ongoing benefit generated from engaging children to support the family on the agriculture mainly on K'hat production. This cash crop, which is perennial, demands large labour consistently throughout the year.

Poor school performance could result into inadequate preparation for economic opportunities, and eventually, the intergenerational poverty cycles could continue consistently (Engle et al. 2007). The vast majority of children in East Africa are not enrolled in pre-primary school and have limited access to early learning opportunities (Michelle and Amanda 2012). In this regard, net pre-primary enrollment rate in 2009/2010 for children between 36 and 59 months was 33\%, 4\%,29\%, and $14 \%$ in Tanzania, Ethiopia, Kenya, and Uganda, respectively. Looking more specifically at changes in enrolment rates in pre-primary school in the last 5 years, we see that while progress has been made, early learning opportunities are far from universal. Table 5 clearly indicates that children spent their time on various economic activities combined with formal education. From the daily activities, education take the lion's share of children's time spending followed by the shepherd and taking care of younger siblings. However, the average time budgeted for education is below the national standard (6 h per day) for attending elementary and junior school, which implies that there are children who allocate zero hours.

The child labour force participation is not normal between the poor and non-poor households in the study area (see Table 6). There was significant difference on the average child labour participation between the poor and the non-poor households of the study area. The mean difference $t$ test clearly showed that children from non-poor households engage more on different activities than the poor ones. 
Table 5 Average hours spent by child on different activities. Source: Own Survey, 2015

\begin{tabular}{ll}
\hline Type of activity & $\begin{array}{l}\text { Average } \\
\text { hours } \\
\text { per day }\end{array}$ \\
\hline Education & 4.8 \\
Shepherd & 3.97 \\
Caring for sibling & 3.5 \\
Farming & 3.0 \\
Firewood fetching & 1.96 \\
Water fetching & 1.42 \\
Other activities & 2.5 \\
\hline
\end{tabular}

Table 6 Child labour allotment by the poor and non-poor households

\begin{tabular}{llllc}
\hline Activities & Combined & Poor & Non-poor & t value \\
\hline Farming & 0.66 & 0.63 & 0.67 & 0.22 \\
Water fetching & 0.53 & 0.35 & 0.59 & $2.25^{* *}$ \\
Firewood fetching & 0.63 & 0.4 & 0.70 & $2.36^{* * *}$ \\
Caring for sibling & 0.5 & 0.6 & 0.12 & -0.69 \\
Shepherd & 2.06 & 1.76 & 2.15 & $1.42^{*}$ \\
Child Labour hour & 4.45 & 3.82 & 4.65 & $1.51^{*}$ \\
\hline
\end{tabular}

***, ${ }^{* *}$ and ${ }^{*} 1 \%, 5 \%$ and $10 \%$ level of significance, respectively

\section{Double-hurdle model estimation result and discussion}

The model result presented below indicates that the overall $F$ value calculated is significant at $1 \%$ significance level, which indicates that the variables included in the regression have coefficients that are jointly different from zero. Many of the explanatory variables are with the expected sign despite some of them are insignificant in affecting the dependent variable, child labour participation. The study considered cropland as a proxy for household wealth in the second tier of the model. Since the crop production is hoe practice type, wherein smallholders of the area do not need oxen to plough, and oxen are not crucial asset to say a household is rich or poor. Thus, livestock are not as such critical like the cropland in farm practice of the area, which was the logic behind considering cropland as a sole proxy in measuring household wealth in the study area.

Cropland holding has positive and significant effect on intensity of child labour participation in the different domestic activities for the respective households in the study area (Tier 2 of Table 7). This implies that children from wealthier households in terms of cropland, which is the main proxy for wealth, spent more hours on domestic work as compared to children from poor households. Children from wealthier households do not have the guarantee to spent more time on their education rather they could be forced to budget more time for domestic activities. Koissy-Kpein (2012) indicated that children of land-rich household are more likely to work in family farm compared to children from poor household in sub-Saharan African countries. Households with larger cropland perform better in terms of the welfare indicators. Nkamleu (2006) has got similar findings about interaction of child labour for work and household's productive cocoa land in Côte d'Ivoire. Bhalotra and Heady (2003) describes the counter-intuitive situation, where children in land-rich households are more likely 
Table 7 Double-hurdle estimation result (dependent variable, child labour participation)

\begin{tabular}{llcc}
\hline Dependent variables & Variable description & Coefficient & $\boldsymbol{Z}$ value \\
\hline Child labour participation (Tier 1) & Sex of household head & -2.60 & -0.29 \\
& Age of household head & -5.25 & -1.11 \\
& Household head education & $-5.99^{*}$ & -1.73 \\
& Cropland owned & -24.64 & -1.57 \\
& Hours for education per day by child & 3.89 & 1.54 \\
& Livestock in TLU & $219.0^{* * *}$ & 6.13 \\
& Household's poverty status (rich was the base) & $-21.0^{*}$ & -1.87 \\
& Adult family member & -1.37 & -0.68 \\
& Location dummy & \\
& Kurfa Chelie & & 3.13 \\
& Kersa & $17.10^{* * *}$ & -0.46 \\
& Fedis & -22.89 & 0.37 \\
& Household head age square & 5.06 & 1.02 \\
& Dependent family members & 0.064 & 0.21 \\
& Constant & 0.306 & 1.15 \\
Cropland owned & 102.0 & 2.36 \\
Sigma & Constant & $3.76^{* *}$ & -1.75 \\
& Constant & $-12.59^{*}$ & 4.7
\end{tabular}

$* * * * *$, and $* 1 \%, 5 \%$ and $10 \%$ level of significance, respectively

a Melka Bello district was the base in constructing dummy variable

to work and less likely to attend school than children from land poor households. Those scholars argued that productive assets such as cropland affect child labour participation in two opposite directions: a negative wealth effect, where large landholdings generate higher income and making easier for household to forgo the income generate by child labour. A positive effect, in the absence of a perfect land and labour market, owner of large cropland who are unable to hire farm labour have an incentive to employ their own children. In this regard, child labour could be a substitute for the hired labour. These all imply that smallholder's ownership of large cropland does not be a guarantee to enhance child school enrolment in the study area.

The model result also reveals that, livestock measured in terms TLU and a proxy for smallholder's wealth, affect child labour participation decision positively and significantly. This result implies that children from households that have larger livestock would have more probability of participating in child labour than the poor ones. The coefficient estimate shows that possession of larger livestock increase the probability of child labour participation. Household's poverty level, which categorizes households into poor and non-poor, also affect child labour participation decision positively. The negative and significant coefficient indicates that children from rich households have higher probability to use labour force as compared to the poor ones. Similarly, location dummy variable have significant effect on child labour participation decision for children from Kurfa Chelie. As it has been discussed, above Kurfa Chelie is the best performing district as far as poverty profile measurement is concerned. In terms of child labour participation, this district has strong and positive probability as compared to the base district, Melka Bello. 
Positive interactions with caregivers and early learning opportunities can improve children's health, educational, and even economic trajectories (Engle et al. 2011). One of the household's demographic characteristics, household head years of education level, affects child labour participation decision negatively and significantly as to the model result (see Table 7). The model result implies that children from households headed by educated individuals had better probability of school enrolment. The likelihood that a child will attend school increases markedly with the education of the household head (Cockburn and Dostie 2007). Shafiq (2007) had similar findings "higher parental education is associated with higher schooling and lower child labour participation." Children from socio-economically poor households highly participate in child labour (Shafiq 2007; Subhash 2011). As it has been expected when the household head has better education or awareness, (s)he will send her/his children to school instead of using them as family labour. The coefficient estimate also provides the same result; the better household head's education the less likely to use the child labour in the household's domestic activities (see Table 7).

\section{Conclusions and recommendations}

\section{Conclusions}

This study examined interaction of household wealth and child labour participation in eastern Ethiopia and evaluate "the Wealth Paradox empirically" considering crosssectional data from randomly selected households from four districts.

Around a quarter of the sample households spent less than what they needed to fulfill their minimum living standard requirement. They are below the absolute poverty line. However, households with better crop production and productive cropland had better capacity of satisfying their minimum requirement.

Even though most of the household heads in the study area are economically active, but they are only basic literate (elementary school graduate). This implies that they do not have an advanced knowledge and understanding about the benefits of child education. The child school dropout and abstain in the study area are because of households' lower awareness about long run benefits of education.

The model result indicates household heads education level affects child labour participation negatively, which implies that increment in the education positively initiate the household to send their children to school.

Moreover, households in the study area do not have the awareness to change assets into productive source of income and additional labour that may reduce burden over their children. If the incidence of child work reduce, then the likelihood of a child to attend school increase.

Significant proportion of households in the study area used their children as a source of labour to supplement the adult family labour for activities that require less physical exertion. In connection to this only $3.7 \%$ of the children fully engaged on their education.

The study found that the higher cropland the household owned, the wealthier it is, the higher the probability that the child would participate in the family labour. The intensity of labour hour budgeted by children increase parallel with household's cropland. 
Possession of large livestock increases the probability of children to participate in labour force. This relationship shows that livestock rich households are not initiated and willing to send their children to school.

In general, it is easy to conclude that, children from wealthier households, in terms of cropland and livestock holding, have higher probability of participating in labour force. Similarly, the amount of time children spent on domestic activities outside their education is high. Finally, the study approved that the "Wealth Paradox" with regard to child labour and household wealth really works in eastern Ethiopia.

\section{Recommendations}

A wide range of national economic benefits could be extracted if the future labour has been cultivated and conserved carefully. Interventions on child education could generate economic rewards to the family, national labour market productivity, labour force diversification. To maximize all the benefits from child education and future labour the following activities ought to be done by the respective stakeholders at each level of operation within the country.

- Alternative source of labour should be identified to reduce the burden on children.

- The concerned party should have devotion to create awareness about modern technology adoptions that reduce human labour demand of the household to increase child school enrolment in the study area.

- NGOs may participate through distributing farm technologies that save child labour, which would guarantee children of the area to attend their education carefully.

- There should be enhancement in the household heads' awareness about benefits of child education. In this regard, the concerned body in the government hierarchy is advised to rearrange trainings and expand education to build smallholders capacity with regard to evaluating long run benefits of child education.

- Both local and foreign NGOs should participate in the area through enhancing awareness of smallholders about short-and long-term benefits of education. Those institutions should change the way and direction of aid and support what they have been providing to beneficiaries of the area.

- Community based type of solutions and supports ought to be expanded to have selfsustain smallholders. Continuous effort should be exerted until they try to clearly evaluate the benefits from child education.

- Profit oriented organizations may participate in provide agricultural inputs at a lower price with simple technology to be adopted easily by smallholders with little knowhow and awareness.

Acknowledgements

The authors thank Haramaya University for securing small research grant to collect the data. This research received no grant more than the required level to collect the data. Any funding agency in the public, commercial or not-for-profit sectors did not participate in the data collection or editing process of this work.

\section{Authors' contributions}

AS conceived the study, collecting and editing the data, performed the analysis and interpretation, and drafted skeleton of the manuscript and critically review the manuscript. KM contributed in the data entry and editing, constructing the model, performing the analysis, interpretation of model result intensively edit the language of the manuscript. Both authors participated in the critical appraisal as well as revision of the manuscript. All authors read and approved the final manuscript. 


\section{Funding}

Not applicable. The study has not funding support from anybody.

\section{Availability of data and materials}

The study used primary data collected by the researchers from sample households in eastern Ethiopia. The data purely belong to the authors and there is no conflict of interest in connection to sharing the data. The data are available and can be shared from the authors.

\section{Competing interests}

Since the data and working material of the research were common to the authors, there is not any sort of conflict of interest. The authors declare that they have no competing interests.

\section{Author details}

${ }^{1}$ Department of Economics, Debre Markos University, Debre Markos, Po.Box. 126, Ethiopia. ${ }^{2}$ Department of Economics, Candidates at Illinois State University, Chicago, USA.

Received: 16 August 2018 Accepted: 6 August 2019

Published online: 26 August 2019

\section{References}

Basu, K., Das, S., \& Dutta, B. (2010). Child labour and household wealth: theory and empirical evidence of an inverted-U. Journal of Development Economics, 91, 8-14.

Bhalotra, S., \& Heady, C. (2003). Child farm labour: The wealth paradox. World Bank economic review (pp. 197-227). UK: Oxford University Press.

Bogale, A., \& Korf, B. (2009). Analysis of poverty and its covariates among smallholder farmers in the eastern Hararghe highlands of Ethiopia, 2009 Conference, August 16-22, 2009, Beijing, China 51469, International Association of Agricultural Economists.

Cameron, C., \& Trivedi, P. (2005). Micro econometrics—Methods and applications. New York: Cambridge University Press.

Charles, D. O., Richard, T., \& Osei-B, Yaw. (2014). Analysis of rural household poverty and farmers' decision on child labour nexus using multinomial logit model. American Journal of Mathematics and Statistics, 4(6), 248-253.

Cockburn, J., \& Dostie, B. (2007). Child work and schooling: The role of household asset profiles and poverty in rural Ethiopia. Journal of African Economies, 16(4), 519-563.

Cragg, J. (1971). Some statistical models for limited dependent variables with applications for the demand for durable goods. Econometrica, 39(5), 829-844.

CSA (Central Statistics Agency) (2008). Annual national population and economic report. Addis Ababa, Ethiopia. Vol. I.

CSA (Central Statistics Agency) (2009). Annual national population and economic report. Addis Ababa, Ethiopia. Vol. I .

Dawit, S. (2010). Determinants of child labour versus schooling in rural Ethiopia. European Journal of Social Sciences, 17(3), 414-425.

Degnet, A., Andinet, D., \& Assefa, A. (2007). Determinants of child schooling progress in rural Ethiopia. Working Paper No 3/07: Ethiopian Economic Association/Ethiopian Economic Policy Research Institute (EEPRI).

Edmonds, E. V., \& Pavcnik, N. (2005). Child labour in the global economy. Journal of Economic Perspectives, 19(1), 199-220.

Engle, P. L., Black, M. M., Behrman, J. R., Cabral de Mello, M., Gertler, P. J., Kapiriri, L., et al. (2007). Strategies to avoid the loss of developmental potential in more than 200 million children in the developing world. The International Child Development Steering Group. The Lancet, 369(9557), 229-242.

Engle, P. L., Fernald, L. C. H., Alderman, H., Behrman, J., O'Gara, C., Yousafzai, A., et al. (2011). Strategies for reducing inequalities and improving developmental outcomes for young children in low-income and middle-income countries. The Lancet, 378(9799), 1339-1353.

FAO. (2006). Meeting charts way forward to eliminate hazardous harm work for children, FAO Newsroom. http://www.fao. org/newsroom/en/news/2006/1000394/index.html.

Fennema, J., \& Sinning, M. (2007). Double-hurdle models with dependent errors and heteroscedasticity. Essen: Heriot-Watt University and RWI-Essen.

Guarcello, L., Lyon, S., \& Rosati, F.C. (2006). The twin challenges of child labour and youth employment in Ethiopia. Understanding Children's work project working paper series. University of Rome: Tor Vergata.

Guarcello, L., \& Rosati, F. (2007). Child Labour and Youth Employment: Ethiopia Country Study, SP Discussion Paper NO. 0704, Understanding Children's Work, UNICEF.

ILO (International Labour Organisation). (2000). Questionnaire: Survey of Children Working on the Street. St. Petersburg Action Committee on the Elimination of Child Labour. Geneva: ILO.

ILO (International Labour Organisation). (2017). Causes and Consequences of Child Labour in Ethiopia.

John, C. (2002). Income Contributions of Child Work in Rural Ethiopia: CSAE WPS/2002-12.

Koissy-Kpein, S.A. (2012). Child labour, schooling and household wealth in African rural area: Luxury axiom or wealth paradox. Working Paper No 2012-08. Développement International CEPS/INSTEAD: Luxembourg: http://www.ceps. lu.

Lorenzo, G., \& Furio, R. (2007). Child Labour and Youth Employment: Ethiopia Country Study: Social Protection Discussion Paper No. 0704: World Bank.

McDowell, A. (2018). From the help desk: Hurdle models. The Stata Journal: Promoting communications on statistics and Stata, 3(2):178-184

Michelle, J. N., \& Amanda, E. D. (2012). Early childhood policies in sub-Saharan Africa: Challenges and opportunities. International Journal of Child Care and Education Policy., 6(2), 21-34. 
Nkamleu, B. G. (2006). Poverty and child farm labour in Africa: Wealth paradox or bad orthodoxy. African Journal of Economic Policy, 13(1), 1-24.

Shafiq, M. N. (2007). Household schooling and child labour decisions in rural Bangladesh. Journal of Asian Economics, 18, 946-966.

Smith, M. D. (2003). On dependency in double-hurdle models. Statistical Papers, 44(4), 581-595.

Solomon, A., Bekele, S., \& Franklin, S. (2010). Does technology adoption promote commercialization? Evidence from Chickpea Technologies in Ethiopia.

Sonia, B., \& Christopher, H. (2003). Child farm labour: The wealth paradox. The World Bank Economic Review, 17(2), 197-227.

Subhash, B. (2011). Socio-economic and demographic impact on child labour in India. Journal of Alternative Perspectives in the Social Sciences, 3(2), 376-403.

Takashi, Y. (2000). Does food aid reduce child farm labour supply in Ethiopia?. Mimeo: The World Bank.

World Bank. (2005). Ethiopia: Well-being and poverty in Ethiopia, the role of agriculture and agency. Washington, DC: The World Bank.

\section{Publisher's Note}

Springer Nature remains neutral with regard to jurisdictional claims in published maps and institutional affiliations.

\section{Submit your manuscript to a SpringerOpen ${ }^{\circ}$} journal and benefit from:

- Convenient online submission

- Rigorous peer review

- Open access: articles freely available online

- High visibility within the field

- Retaining the copyright to your article

Submit your next manuscript at $\boldsymbol{\Delta}$ springeropen.com 